\title{
Agrobacterium-mediated transformation of indica rice under Acetosyringone-free conditions
}

\author{
Mangu Venkata Ramana Rao, Gundimeda Jwala Narasimha Rao* \\ Division of Crop Improvement, Central Rice Research Institute, Cuttack-753 006, Orissa, India \\ *E-mail: gjnrao@yahoo.com Tel: +91-0671-2367777-ext.271 Fax: +91-0671-2367663
}

Received March 9, 2007; accepted October 23, 2007 (Edited by M. Nakano)

\begin{abstract}
The possibility of developing transgenic indica rices through Agrobacterium-mediated transformation in the absence of acetosyringone at bacterial preinduction or co-cultivation or both stages was assessed. Four-week-old, scutellum derived calluses of indica rice (Oryza sativa L. cv. 'Pusa Basmati1') were co-cultivated with A. tumefaciens strain LBA4404 (pSB1), harboring the binary vector pCAMBIA 1301 with the $\beta$-glucuronidase (GUS) and hygromycin phosphotransferase (HPT) genes in the T-DNA region. Addition of acetosyringone (AS) to both preinduction medium (PIM) and co-cultivation medium (CCM) induced higher levels of transient GUS expression than that obtained with the addition of AS to either of the stages. Addition of only sucrose to both preinduction and co-cultivation media yielded transient expression levels similar to those obtained by the addition of AS. The resultant fertile plants were stable transformants as revealed by GUS histochemical assay and PCR analysis for the GUS and HPT genes. Thus, phenolics like AS may not be essential for induction of vir genes, and development of transgenic indica rice is feasible under AS-free conditions.
\end{abstract}

Key words: Acetosyringone, Agrobacterium, indica rice, transformation, transgenic plant.

Among the currently available plant transformation techniques, Agrobacterium method, a simple natural gene transfer system, is the most widely used one for genetic improvement of several crop species including rice. The processing and transfer of T-DNA from $A$. tumefaciens to plant cells is mediated by the combined action of both chromosomal (chv) and vir genes (virA, $-B,-G,-C,-D$ and $-E)$. The vir genes are induced by phenolics such AS, and at low AS concentration vir gene induction is augmented by certain wound-induced sugars in plant cells (Stachel et al. 1985; Bolton et al. 1986; Spencer and Towers 1988; Melchers et al. 1989; Huang et al. 1990). To date, all the successful reports on Agrobacterium-mediated transformation of rice have been based on Agrobacterium preinduction and/or cocultivation in the presence of AS (Hiei et al. 1994; Aldemita et al. 1996; Rashid et al. 1996; Khanna et al. 1999; Datta et al. 2000; Hashizume et al. 2006) or based on co-cultivation in presence of suspension culture of potato cells, a rich source of phenolic compounds (Chan et al. 1993). No transient expression of the GUS gene was observed in the absence of AS even when using a super virulent Agrobacterium strain, and $100 \mu \mathrm{M}$ of AS was reported to be optimum for transient expression in rice (Azhakanandam et al. 2000).

We examined the influence of AS at different steps of Agrobacterium-mediated transformation of a indica rice and report the feasibility of transformation of recalcitrant indica genotype with simple sugars like sucrose in the absence of AS.

The scutellum-derived embryogenic calluses obtained from a popular long grain aromatic indica rice (Oryza sativa L) cultivar, Pusa Basmatil was used as a target material for transformation. Media used for culture and transformation are listed in Table 1. Mature seeds washed with sterile water were surface sterilized successively with, $70 \%$ ethanol for two min, sodium hypochlorite (contains 4\% (v/v) active chlorine) for $15 \mathrm{~min}$ and with $0.1 \%(\mathrm{w} / \mathrm{v})$ aqueous mercuric chloride solution for $5 \mathrm{~min}$ with in between repeated washings with sterile water. These seeds were placed on semisolid MS (Murashige and Skoog 1962) callus induction (CI) CI medium contained in culture tubes and incubated at $25 \pm 2^{\circ} \mathrm{C}$ in the dark. After three weeks, the induced calluses were subcultured onto fresh CI medium. After 4-7 days of incubation, the embryogenic callus cultures with somatic embryos were selected for transformation.

The selected embryogenic calluses were transformed with a super virulent $A$. tumefaciens strain LBA4404 (pSB1) (Komari et al. 1996) containing pCAMBIA 1301 (CAMBIA MGRS Accession number TG148). This binary vector carried intron-containing GUS and HPT genes in the T-DNA region. One loop of bacterial cells was streak-inoculated on yeast extract peptone (YEP)

Abbreviations: AS, acetosyringone; GUS, $\beta$-glucuronidase; HPT, hygromycin phosphotransferase; Hyg ${ }^{\mathrm{R}}$, hygromycin-resistant

This article can be found at http://www.jspcmb.jp/ 
Table 1. Media used for tissue culture and transformation of rice.

\begin{tabular}{|c|c|}
\hline Medium & Composition \\
\hline CI & $\begin{array}{l}\text { MS salts and vitamins, } 30 \mathrm{~g}^{-1} \text { sucrose, } 500 \mathrm{mg}^{-1} \text { L-proline, } 300 \mathrm{mg}^{-1} \text { casein hydrolysate and } 2.0 \mathrm{mg} 1^{-1} \text { 2, 4-D, } \\
2.25 \mathrm{~g}^{-1} \text { phytagel, pH } 5.8\end{array}$ \\
\hline $\mathrm{CCM}$ & $\begin{array}{l}\text { MS salts and vitamins, } 30 \mathrm{~g}^{-1} \text { sucrose, } 500 \mathrm{mg}^{-1} \mathrm{~L} \text {-proline, } 300 \mathrm{mg}^{-1} \text { casein hydrolysate and } 2.0 \mathrm{mg}^{-1} \text { 2, 4-D, } \\
8.5 \mathrm{~g}^{-1} \text { agar, } \mathrm{pH} 5.8\end{array}$ \\
\hline CI-SL & $\begin{array}{l}\text { MS salts and vitamins, } 30 \mathrm{gl}^{-1} \text { sucrose, } 500 \mathrm{mg}^{-1} \mathrm{~L} \text {-proline, } 300 \mathrm{mg}^{-1} \text { casein hydrolysate and } 2.0 \mathrm{mg}^{-1} 2 \text {, 4-D, } \\
30 \mathrm{mg}^{-1} \text { hygromycin and } 125 \mathrm{mg} \mathrm{l}-1 \text {, cefotaxime and } 125 \mathrm{~m} \mathrm{l}^{-1} \text { carbencillin , } 2.25 \mathrm{~g}^{-1} \text { phytagel, } \mathrm{pH} 5.8\end{array}$ \\
\hline PRE-RE & $\begin{array}{l}\text { MS salts and vitamins, } 30 \mathrm{~g} \mathrm{l}^{-1} \text { sucrose, } 20 \mathrm{~g} \mathrm{l}^{-1} \text { sorbitol, } 1 \mathrm{mg}^{-1} \text { naphthaleneacetic acid, } 2 \mathrm{mg} 1^{-1} \text { kinetin, } \\
30 \mathrm{mg}^{-1} \text { hygromycin, } 2.25 \mathrm{~g}^{-1} \text { phytagel, } \mathrm{pH} 5.8\end{array}$ \\
\hline $\mathrm{RE}$ & $\begin{array}{l}\text { MS salts and vitamins, } 30 \mathrm{~g}^{-1} \text { sucrose, } 0.5 \mathrm{mg}^{-1} \text { naphthaleneacetic acid , } 0.5 \mathrm{mg}^{-1} \text { kinetin, } 1.5 \mathrm{mg}^{-1} \text { benzylaminopurine, } \\
5 \mathrm{~g}^{-1} \text { phytagel, } \mathrm{pH} 5.8\end{array}$ \\
\hline RT & MS salts and vitamins, $50 \mathrm{~g}^{-1}$ sucrose, $1.0 \mathrm{mg}^{-1}$ naphthaleneacetic acid, $0.1 \mathrm{mg}^{-1}$ kinetin, $7 \mathrm{~g}^{-1}$ agar, $\mathrm{pH} 5.8$ \\
\hline PIM & $\mathrm{AB}$ buffer and salts, $5 \mathrm{gl}^{-1}$ sucrose \\
\hline
\end{tabular}

Table 2. Effect of acetosyringone and sucrose on transient transformation frequency.

\begin{tabular}{|c|c|c|c|c|c|c|}
\hline \multirow{2}{*}{ Treatment } & \multicolumn{2}{|c|}{ PIM } & \multicolumn{2}{|c|}{$\mathrm{CCM}$} & \multicolumn{2}{|c|}{$\begin{array}{l}\text { GUS expression zones }{ }^{\dagger} \\
\text { (means } \pm \mathrm{SD})\end{array}$} \\
\hline & AS & Sucrose & AS & Sucrose & Large & Small \\
\hline A & + & + & - & + & $20 \pm 0.1$ & $34 \pm 5.7$ \\
\hline B & - & + & + & + & $24 \pm 4.9$ & $32 \pm 2.1$ \\
\hline $\mathrm{C}$ & + & + & + & + & $33 \pm 1.4$ & $54 \pm 4.2$ \\
\hline $\mathrm{D}$ & - & + & - & + & $19 \pm 2.8$ & $59 \pm 6.4$ \\
\hline
\end{tabular}

$\uparrow$ Pooled data of two experiments with hundred explants each (SD, standard deviation).

A Preinduction of Agrobacterium in presence of AS and sucrose followed by co cultivation in the absence of AS.

${ }^{B}$ Preinduction of Agrobacterium in absence of AS and presence of sucrose followed by co-cultivation in the presence of AS and sucrose

C Preinduction of Agrobacterium in presence of both AS and sucrose followed by co-cultivation both in the in presence of AS and sucrose

D Preinduction of Agrobacterium in absence of AS followed by co-cultivation in the absence of AS.

medium (Lichtenstein et al. 1986) dispensed in Petri dishes and the plates were incubated at $28^{\circ} \mathrm{C}$ for two days. A single colony of the bacterium was picked up and reinoculated on $\mathrm{AB}$ minimal medium (Chilton et al. 1974) supplemented with $0.5 \%(\mathrm{w} / \mathrm{v})$ glucose and incubated for two days at $28^{\circ} \mathrm{C}$. From this culture, 2-4 single colonies of the bacterium were transferred to 25 $\mathrm{ml}$ of $\mathrm{AB}$ minimal medium containing $5 \mathrm{gl}^{-1}$ sucrose dispensed in $100 \mathrm{ml}$ Erlenmeyer flasks. The flasks were incubated under agitation on an orbital shaker $(220 \mathrm{rpm})$ at $25^{\circ} \mathrm{C}$. After $24-48 \mathrm{~h}, 0.5 \mathrm{ml}$ of the bacterial cell suspension culture was again inoculated to $50 \mathrm{ml}$ of fresh medium of the same composition and incubated under conditions described above for $14-20 \mathrm{~h}$. The bacterial cell suspension, adjusted to 0.6 O.D $\left(\mathrm{A}_{620}\right)$ with sterile sucrose supplemented $\mathrm{AB}$ minimal medium was directly used for infection. Three different antibiotics, kanamycin $\left(100 \mathrm{mgl}^{-1}\right)$, tetracycline $\left(5 \mathrm{mgl}^{-1}\right)$, and rifampicin $\left(10 \mathrm{mgl}^{-1}\right)$ were used for culturing the bacterium on solid medium, while for culturing the bacterium in all liquid media, two antibiotics, kanamycin $\left(50 \mathrm{mg} \mathrm{l}^{-1}\right)$ and tetracycline $\left(2.5 \mathrm{mg} \mathrm{l}^{-1}\right)$ were used. In treatments aimed at evaluating the influence of AS on transformation frequency (Table 2), $50 \mu \mathrm{M}$ AS was added to the bacterial culture $4 \mathrm{~h}$ before co-cultivation.

Inoculation and co-cultivation were performed according to Datta et al. (1997) with minor modifications. Four- week-old embryogenic calluses were inoculated with Agrobacterium by immersing them in the bacterial cell suspension dispensed in Petriplates $(90 \times 15 \mathrm{~mm})$ which were gently agitated on an orbital shaker $(80-100 \mathrm{rpm})$ for $15-30 \mathrm{~min}$. The calluses were then blotted on sterile filter paper under aseptical conditions to remove excess bacterial cells and were placed on CCM medium with or without $50 \mu \mathrm{M} \mathrm{AS}$ at $25^{\circ} \mathrm{C}$ in dark for three days for co-cultivation. At the end of the incubation, the calluses were washed with $\mathrm{CI}$ medium without phytagel but supplemented with $125 \mathrm{mg}^{-1}$ cefotaxime and $125 \mathrm{mgl}^{-1}$ carbenicillin, dried on sterile filter paper, and transferred to selection (CI-SL) medium. The calluses were passed through four selection cycles of 15 days each. All growing calluses during the fourth selection cycle $\left(\mathrm{Hyg}^{\mathrm{R}}\right.$ calluses) were transferred to pre regeneration (PRE-RE) medium and incubated for two weeks. The calluses were then transferred to RE medium. Regenerated green shoots thus obtained were transferred to rooting (RT) medium for root induction and development. These putative transgenic plants were planted in earthen pots containing sterile field soil and grown until maturity in an isolated greenhouse.

GUS activity is localized, and generally, transient GUS gene expression analysis is performed with inoculated tissues that are not exposed to antibiotics during cocultivation stage (Rueb et al. 1989). For histochemical 
detection, segments (5 $\mathrm{mm}$ in length) of rice tissues were incubated in a reaction mixture of $50 \mathrm{mM}$ phosphate buffer (pH 6.8), $1 \%$ Triton $\mathrm{X}-100,20 \%$ methanol and $1 \mathrm{mM}$ 5-bromo-4-chloro-3-indolyl- $\beta$-D-gluronide (Xgluc). The reaction was initiated under a mild vacuum for few min and carried out overnight at $37^{\circ} \mathrm{C}$. The frequency of transient transformation is expressed as the ratio between the number of calli showing GUS expression and the total number of calli kept for staining. For qualitative assay, the area of GUS expression and intensity of the blue colour at each spot were given due weightage so as to give a holistic picture of the effects of the various treatments tested. Through visual observations, distinction could be made between small spots $(<0.5 \mathrm{~mm}$ in diameter) representing one or few GUS expressing cells, and large spots $(\geq 1 \mathrm{~mm}$ in diameter), representing a complete cell cluster expressing the GUS gene (De Clercq et al. 2002). Based on both quantitative and qualitative assays, the efficacy of acetosyringone was evaluated.

Confirmation for stable integration of GUS and HPT genes in rice genome was obtained by polymerase chain reaction (PCR) analyses. Genomic DNA was extracted from the leaves of putative transgenic plants $\left(\mathrm{T}_{0}\right)$ and non-transformed (wild type) plants by CTAB method (Murray and Thompson., 1980). Primers (GUS-F-5'GGT GGG AAA GCG CGT TAC AAG-3' and GUS-R5'-GTT TAC GCG TTG CTT CCG CCA-3') specific for GUS and (HPT-F- 5'-GCC TGA ACT CAC CGC GAC G-3' and HPT-R-5'-CAG CCA TCG GTC CAG ACG$\left.3^{\prime}\right)$ specific for HPT genes were employed. PCR was performed in a $25 \mu \mathrm{l}$ reaction volume containing $17.5 \mu \mathrm{l}$ sterilized nanopure water, $2.5 \mu \mathrm{l}$ of $10 \times \mathrm{PCR}$ buffer, $1 \mu \mathrm{l}$ (concentration $100 \mathrm{ng}$ ) of each primer, $1 \mu \mathrm{l}$ of dNTPs mix $\left(0.2 \mathrm{mM}\right.$ of each dNTP), and $1 \mu \mathrm{l}\left(0.5 \mathrm{U} \mu \mathrm{l}^{-1}\right)$ of Taq polymerase and $1 \mu \mathrm{l}(50-100 \mathrm{ng})$ of template DNA. Amplification was performed in a programmable Thermal cycler (PTC-100) (MJ-Research, US) under following conditions. GUS gene: $1 \times\left(94^{\circ} \mathrm{C}\right.$ for $\left.5 \mathrm{~min}\right)$, $40 \times\left(94^{\circ} \mathrm{C}\right.$ for $30 \mathrm{~s}, 55^{\circ} \mathrm{C}$ for $30 \mathrm{~s}, 72^{\circ} \mathrm{C}$ for $\left.1 \mathrm{~min}\right)$, $1 \times\left(72^{\circ} \mathrm{C}\right.$ for $\left.10 \mathrm{~min}\right)$ and HPTgene: $1 \times\left(94^{\circ} \mathrm{C}\right.$ for $\left.5 \mathrm{~min}\right)$, $40 \times\left(94^{\circ} \mathrm{C}\right.$ for $1 \mathrm{~min}, 58^{\circ} \mathrm{C}$ for $1 \mathrm{~min}, 72^{\circ} \mathrm{C}$ for $\left.1 \mathrm{~min}\right)$, $1 \times\left(72^{\circ} \mathrm{C}\right.$ for $\left.5 \mathrm{~min}\right)$. Fifteen microliters of the PCR product was resolved on ethidium-bromide-stained $0.8 \%$ agarose gel for visualization of the bands.

The experiment was aimed to assess the need for acetosyringone at PIM (Agrobacterium culture) or cocultivation or both stages for Agrobacterium-mediated gene transfer to rice calluses. Addition of AS for both stages induced high levels of GUS expression zones ( $\sim 33$ large and $\sim 54$ small zones) consistently in contrast to low levels of expression in the presence of AS either only at PIM ( $\sim 20$ large and $\sim 34$ small $)$ or only at CCM ( $\sim 24$ large and $\sim 32$ small) stages. Nevertheless, GUS expression zones obtained in treatment where AS was added to CCM and in those where AS was added at both PIM and CCM stages did not differ qualitatively (Figure 1A, B, C). Interestingly, similar levels of GUS expression zones were also obtained in sucrosesupplemented media devoid of AS in PIM or CCM or both ( $\sim 20$ large and $\sim 60$ small) (Figure 1D).

In addition to high transient GUS expression under AS-free conditions, stable transformation was achieved with both AS and AS-free plus sucrose treatments (Table 3). After four selection cycles, the actively proliferated calluses (generated under AS-free conditions) on selection medium showed stable GUS expression (Figure 1E) and the GUS positive calluses produced normal green shoots on RE medium. The stable integration of GUS and hygromycin genes in putative transgenic plants was confirmed by the amplification of expected sizes of GUS and HPT gene
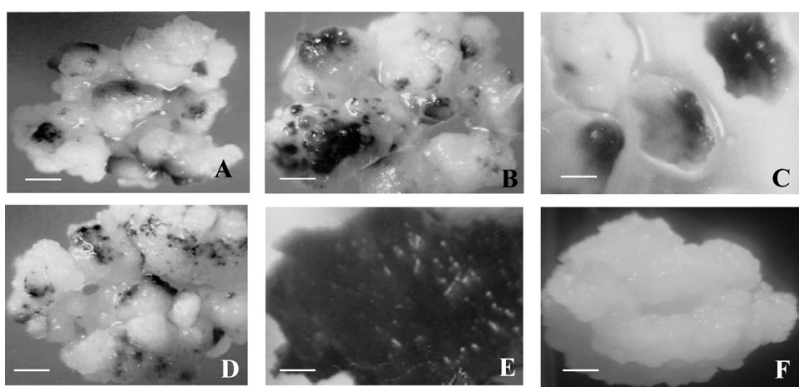

Figure 1. Histological GUS assay of calli after co-cultivation with Agrobacterium. (A) Transient GUS gene expression in calli following preinduction in presence of AS and co-cultivation in the absence of AS. Bar $=1 \mathrm{~mm}$. (B) Transient GUS gene expression in calli following preinduction in absence of AS and co-cultivation in the presence of AS. Bar $=0.6 \mathrm{~mm}(\mathrm{C})$ Transient GUS gene expression in calli following preinduction and co-cultivation both in the in presence of AS. Bar $=0.6 \mathrm{~mm}$ (D) Transient GUS gene expression in calli following preinduction and co-cultivation both in the in absence of AS. Bar $=1 \mathrm{~mm}$ (E) Stable GUS gene expression in $\mathrm{Hyg}^{\mathrm{R}}$ callus 60 day after co-cultivation. Bar $=0.5 \mathrm{~mm}(\mathrm{~F})$ Untransformed callus showing no GUS activity. Bar $=0.5 \mathrm{~mm}$.

Table 3. Influence of AS on Agrobacterium-mediated indica rice transformation.

\begin{tabular}{|c|c|c|c|c|c|}
\hline \multirow[b]{2}{*}{ Co-cultivation } & \multicolumn{4}{|c|}{ Number of scutellum-derived calli } & \multirow{2}{*}{$\begin{array}{c}\text { Transformation } \\
\text { frequency }(\%) \\
(\mathrm{B} / \mathrm{A})\end{array}$} \\
\hline & $\begin{array}{l}\text { Number of calli } \\
\text { co-cultivated (A) }\end{array}$ & $\begin{array}{l}\text { Number of } \mathrm{Hyg}^{\mathrm{R}} \\
\text { calli produced }\end{array}$ & $\begin{array}{c}\text { Number of } \mathrm{Hyg}^{\mathrm{R}} \\
\text { and GUS + calli } \\
\text { produced }\end{array}$ & $\begin{array}{l}\text { Number of } \mathrm{Hyg}^{\mathrm{R}} \\
\text { and GUS + plants } \\
\text { regenerated (B) }\end{array}$ & \\
\hline With AS & 114 & 22 & 16 & 21 & 18.4 \\
\hline Without AS & 92 & 15 & 9 & 7 & 7.6 \\
\hline
\end{tabular}



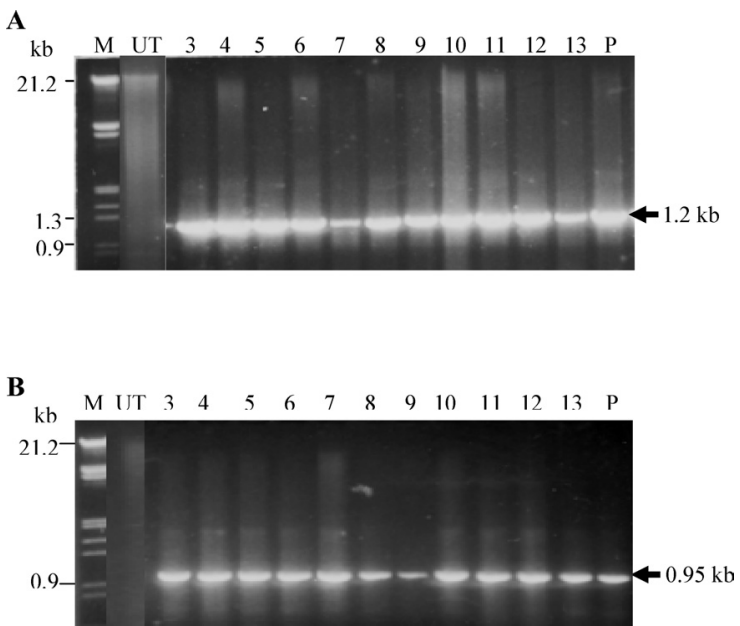

Figure 2. Polymerase chain reaction analysis, showing integration of the coding region of GUS $(1.2 \mathrm{~kb})(\mathrm{A})$ and HPT $(0.95 \mathrm{~kb})(\mathrm{B})$ genes in the genome of randomly selected putative transgenic plants. Lane $\mathrm{M}, \lambda$ DNA EcoRZ/HindIII double digest as size marker; Lanes 3-8, plants obtained after preinduction and co-cultivation both in the presence of AS; lanes 9-13, plants obtained after preinduction and co-cultivation both in the absence of AS; lane P, pCAMBIA 1301 as a positive control; lane UT, untransformed plant as a negative control.

fragments $(\sim 1.2 \mathrm{~kb}$ and $0.95 \mathrm{~kb}$ respectively) with DNA from $\mathrm{T}_{0}$ generation plants (six plants derived from ASsupplemented calli and five plants derived from sucrose supplemented calli), while amplification was negative with DNA from non transformed control plants (Figure 2A, B). All the transgenic plants were fertile and yielded viable seeds in quantities comparable with those of nontransformed plants. Our results provide strong evidence for the first time that acetosyringone may not be essential for the induction of vir genes of Agrobacterium during co-culture for transformation of recalcitrant genotypes like indica rices.

\section{Acknowledgements}

We thank Dr Richard A. Jeffrson, CAMBIA Canberra, Australia for providing pCAMBIA1301. We also wish to express our gratitude to Dr. K. Veluthambi, Madurai Kamaraj University, Tamil Nadu, India for providing the Agrobacterium strain. The authors are grateful to Rockefeller Foundation and International Rice Research Institute for the financial support in the form of a grant (ICAR/IRRI/CRRI collaborative project grant). M.V.Ramana Rao is grateful to the Rockefeller Foundation and Indian Council of Agricultural Research (ICAR) for providing a Senior Research Fellowship. The authors also thank Dr. R.Sridhar for his critical review of the manuscript.

\section{References}

Aldemita RR, Hodges TK (1996) Agrobacterium tumefaciensmediated transformation of japonica and indica rice varieties. Planta 199: 612-617

Azhakanandam K, McCabe MS, Power JB, Lowe KC, Cocking EC,
Davey MR (2000) T-DNA transfer, integration, expression and inheritance in rice: effects of plant genotype and Agrobacterium super-virulence. J Plant Physiol 157: 429-439

Bolton GW, Nester EW, Gordon MP (1986) Plant phenolic compounds induced expression of the Agrobacterium tumefaciens loci needed for virulence. Science 232: 983-984

Chan MT, Chang HH, Ho SL, Tong WF, Yu SM (1993) Agrobacterium-mediated production of transgenic rice plants expressing a chimeric alpha-amylase promoter/ $\beta$-glucuronidase gene. Plant Mol Biol 22: 491-506

Chilton MD, Currier TC, Farrand SK, Bendich AJ, Gordon MP, Nester EW (1974) Agrobacterium tumefaciens DNA and PS8 bacteriophage not detected in crown gall tumors. Proc Natl Acad Sci USA 71: 3672-3676

Datta K, Koukolíková-Nicola Z, Baisakh N, Oliva N, Datta SK (2000) Agrobacterium-mediated engineering for sheath blight resistance of indica rice cultivars from different ecosystems. Theor Appl Genet 100: 832-839

Datta SK, Torrizo LB, Tu J, Oliva N, Datta K (1997) Production and molecular evaluation of transgenic rice plants. IRRI Discussion Paper Series No: 21

De Clercq J, Zambre M, Van Montagu M, Dillen W, Angenon G (2002) An optimized Agrobacterium-mediated transformation procedure for Phaseolus acutifolius A.Gray. Plant Cell Rep 21: 333-340

Hashizume F, Nakazaki T, Tsuchiya T, Matsuda T (2006) Effectiveness of genotype-based selection in the production of marker-free and genetically fixed transgenic lineages: ectopic expression of a pistil chitinase gene increases leaf-chitinase activity in transgenic rice plants without hygromycin-resistance gene. Plant Biotechnol 23: 349-356

Hiei Y, Ohta S, Komari T, Kumashiro T (1994) Efficient transformation of rice (Oryza sativa L.) mediated by Agrobacterium and sequence analysis of the boundaries of TDNA. Plant J 6: 271-282

Huang MLW, Cangelosi GA, Halperin W, Nester EW (1990) A chromosomal Agrobacterium tumefaciens gene required for effective plant signal transduction. J Bacteriol 168: 1291-1301

Khanna HK, Raina SK (1999) Agrobacterium-mediated transformation of indica rice cultivars using binary and super binary vectors. Aust J Plant Physiol 26: 311-324

Komari T, Hiei Y, Saito Y, Murai N, Kumashiro T (1996) Vectors carrying two separate T-DNAs for co-transformation of higher plants mediated by Agrobacterium tumefaciens and segregation of transformants free from selection markers. Plant $J 10$ : 165-174

Lichtenstein C, Draper J (1986) Genetic engineering of plants. In: Glover, DM (ed.) DNA cloning, IRL Press, Washington, DC. pp 67-119

Melchers LS, Regensburg-Tuink AJG, Schilperoort RA, Hooykaas PJJ (1989) Specificity of signal molecules in the activation of Agrobacterium virulence gene expression. Mol Microbiol 3: 969-977

Murashige T, Skoog F (1962) A revised medium for rapid growth and bioassays with tobacco tissue cultures. Physiol Plant 15: 473-497

Murray MG, Thompson WF (1980) Rapid isolation of higher molecular weight plant DNA. Nucl Acids Res 8: 4321-4325

Rashid H, Yokoi S, Toriyama K and Hinata K (1996) Transgenic plant production mediated by Agrobacterium in Indica rice. Plant Cell Rep 15: 727-730

Rueb S, Hensgens LAM (1989) Improved histochemical staining 
for $\beta$-glucuronidase activity in monocotyledonous plants. Rice Genet Newslett 6: 168-169

Spencer PA, Towers GHN (1988) Specificity of signal compounds detected by Agrobacterium tumefaciens. Phytochemistry 27: 2781-2785
Stachel SE, Messens E, Van Montagu M, Zambryski P (1985) Identification of signal molecules produced by wounded plant cells that activate T-DNA transfer in Agrobacterium tumefaciens. Nature 318: 624-629 